Innlegg på inntil 400 ord lastes opp i http://mc.manuscriptcentral.com/tidsskriftet.

Redaksjonen forbeholder seg retten til å foreta redaksjonelle endringer.

Forfattere av vitenskapelige artikler har automatisk tilsvarsrett (jf. Vancouver-gruppens regler).

\section{HPV-testing og livmorhalskreft}

Vi takker for interessen for vår artikkel $(1,2)$. Bjørn Hagen og Kåre Augensen (3) synes å oppfatte at vi anbefaler direkte konisering uten histologisk verifisering ved positiv HPV-mRNA-test sammen med høygradig cytologi og dersom kvinnen er eldre enn 40 år. Vi understreker at Universitetssykehuset Nord-Norge (UNN) følger de nasjonale retningslinjene slik de er nedfelt i Veileder for gynekologisk onkologi 2009, og vi er selvfølgelig også enige i at retningslinjene ikke kan endres på bakgrunn av en retrospektiv studie.

Hensikten med masseundersøkelsen mot livmorhalskreft er å identifisere kvinner med høygradige forstadier til livmorhalskreft (CIN2+) slik at disse kan få behandling før kreft utvikles. Vår studie viser at positiv HPV-mRNA-test har høy positiv prediktiv verdi for histologisk CIN2+ (2). Tall fra Kreftregisteret viser at $88,1 \%$ av kvinner med histologisk bekreftet CIN2+ får påvist CIN2+ i cervixkonus (4). Til sammenligning viser vår studie at $94,2 \%$ av kvinner med cytologisk høygradig interepitelial neoplasi (HSIL) og positiv HPV mRNA-test får påvist histologisk CIN2+ (2).

Det ser ut som om positiv prediktiv verdi (PPV) for kreft er høyere ved positiv HPVmRNA-test enn ved histologisk bekreftet CIN2 $(5,6)$. I vår studie fant vi 13 kvinner med utviklet kreft til tross for lavgradig cytologi seks måneder tidligere (2).

Som vi formulerte i vår omtale av artikkelen (1), kan resultatene indikere at kvinner med cytologisk høygradige celleforandringer og positiv HPV-mRNA-test kan behandles direkte uten forutgående biopsi. Våre tall viser at det for kvinner over 40 år som ikke planlegger flere barn, kan synes fornuftig å behandle direkte, uavhengig av resultat på cytologisk prøve. Dette er konklusjonene som ble publisert i PLoS ONE (2), og som også ble referert i Tidsskriftet (1). À påstå at dette er det samme som å anbefale behandlingsstrategier i strid med gjeldende nasjonale retningslinjer, må skyldes en misforståelse.

Det planlegges nå prospektive studier i Danmark og Tyskland for å undersøke om direkte konisering er hensiktsmessig behandling hos noen kvinner. Dersom resultatene kan bekreftes i prospektive studier, er det ikke umulig at retningslinjene i fremtiden kan bli endret fra morfologisk vurde- ring av cytologi og histologi til bruk av molekylære markører for å identifisere kvinnene med høyest risiko for kreftutvikling.

\section{Sveinung Sørbye \\ Silje Fismen \\ Tore Jarl Gutteberg \\ Elin Mortensen}

Litteratur

1. Sørbye S. HPV-mRNA-test påviser celleforandringer. Tidsskr Nor Legeforen 2010; 130: 2214.

2. Sørbye SW, Fismen S, Mortensen E et al. Triage of women with minor cervical lesions: data suggesting a «test and treat» approach for HPV E6/E7 mRNA-testing. PLoS One 2010; 5: e12724.

3. Hagen B, Augensen K. Villedende om HPV-testing. Tidsskr Nor Legeforen 2011; 131: 14

4. Kreftregisteret. Masseundersøkelsen mot livmorhalskreft - årsrapport 2008.

5. Sørbye SW, Fismen S, Mortensen E et al. HPV mRNA-test in women with minor cervical lesions: experience of the University Hospital of North Norway. J Virol Methods 2010; 169: 219-22.

6. Sørbye S. HPV, celleforandringer og kreft. Bioingeniøren 2010; 11: 6-12.

\section{UV-A-stråling og melanomer}

I nr. 18/2010 omtalte Veierød og medarbeidere sammenhengen mellom solarier og hudkreft (1). Vi har i 30 år hevdet at soling, særlig bråsoling, er hovedårsaken til hudkreft og vist det ved nord-sør-gradienter $\mathrm{i}$ insidens, kroppsfordeling osv. (2). Dette er nå allment akseptert.

For melanomer er epidemiologien mer komplisert $(2,3)$. Utearbeidende bønder og fiskere har forbausende lav risiko. Ikke-melanomer skyldes mest UV-B $(280-315 \mathrm{~nm})$, mens vi trodde at melanomer kunne forårsakes av både UV-B og UV-A (315-400 nm) (2), og at UV-A var særlig melanominduserende (3). Setlows banebrytende fiskeeksperimenter fra 1993 (som bekreftet UV-A-strålingens melanominduserende effekt) kan imidlertid være feil (4). Melanomer kan induseres $i$ transgene mus og Monodelphis domestica ved UV-B, men ikke ved UV-A $(2,5)$. Flere nyere epidemiologiske undersøkelser synes å gå i motsatt retning (6-8).

Bruk av solarier (som gir relativt mye UV-A) synes å gi økt risiko for melanom. Tidligere epidemiologiske studier, utført med sterkere solarier enn nå, viste ingen klar melanomrisiko (9). Vi får imidlertid tro at de nyere undersøkelsene er best. Nye dyreforsøk viser altså at UV-A ikke gir melanomer, mens nye epidemiologiske solariestudier antyder det motsatte $(1,6-8)$. Problemet er altså ikke løst, og vi må vente på ny forskning, som vil være av stor helsemessig betydning, siden både sol og solarier gir mye D-vitaminer (5), solen bare om sommeren. D-vitaminets mange helsevirkninger er nå lærebokstoff.

\section{Asta Juzeniene}

Oslo universitetssykehus

\section{Johan Moan}

Oslo universitetssykehus

og

Fysisk institutt

Universitetet i Oslo

Litteratur

1. Veierød MB, Nilsen LT, Robsahm TE. Solarier, vitamin D og hudkreft. Tidsskr Nor Legeforen 2010; 130: 1818-21

2. Moan J, Porojnicu AC, Dahlback A. Ultraviolet radiation and malignant melanoma. Adv Exp Med Biol 2008; 624: 104-16.

3. Moan J, Dahlback A, Setlow RB. Epidemiological support for an hypothesis for melanoma induction indicating a role for UVA radiation. Photochem Photobiol 1999: 70: 243-7.

4. Mitchell DL, Fernandez AA, Nairn RS et al. Ultraviolet $A$ does not induce melanomas in a Xiphophorus hybrid fish model. Proc Natl Acad Sci U S A 2010; 107: 9329-34.

5. Cicarma E, Porojnicu AC, Lagunova Z et al. Sun and sun beds: inducers of vitamin $D$ and skin cancer. Anticancer Res 2009; 29: 3495-500.

6. Veierød MB, Adami HO, Lund E et al. Sun and solarium exposure and melanoma risk: effects of age, pigmentary characteristics, and nevi. Cancer Epidemiol Biomarkers Prev 2010; 19: 111-20.

7. Lazovich D, Vogel RI, Berwick M et al. Indoor tanning and risk of melanoma: a case-control study in a highly exposed population. Cancer Epidemiol Biomarkers Prev 2010; 19: 1557-68.

8. Autier P, Doré JF, Eggermont AM et al. Epidemiological evidence that UVA radiation is involved in the genesis of cutaneous melanoma. Curr Opin Oncol 2010; doi: 10.1097/CC0.0b013e3283436e5d.

9. International Agency for Research on Cancer. The association of use of sunbeds with cutaneous malignant melanoma and other skin cancers: A systematic review. Int J Cancer 2007; 120: $1116-22$

\section{M.B. Veierød}

og medarbeidere svarer:

Takk for interessen for oversiktsartikkelen (1). Sammenfallende resultater fra ulike undersøkelser er avgjørende når råd til befolkningen utformes.

Som Juzeniene \& Moan skriver, finnes det ikke fullgode dyremodeller for induksjon av malignt melanom, og dyrestudiene gir motstridende resultater om effekten av UV-B- og UV-A-stråling.

Solarier gir begge typer stråling (1). 